\title{
CSR Spendings of Indonesia's IPO Prospectuses
}

\author{
Zuraida Zuraida ${ }^{1}$, Sugianto Sugianto ${ }^{2}$ \\ ${ }^{1}$ Faculty of Economics and Business, Syiah Kuala University, Indonesia \\ ${ }^{2}$ Faculty of Agriculture, Syiah Kuala University, Indonesia \\ *Corresponding Author: zuraida@feb.unsyiah.ac.id
}

\begin{abstract}
To raise large amounts of capital, companies usually conduct Initial Public Offerings (IPOs), which allows them to reach large numbers of potential investors. Prospectuses are used to inform the public of the nature and prospects of these offers. The prospectus contains financial and non-financial information such as Corporate Social Responsibility (CSR) spending. However, the level of disclosure is usually not uniform across companies. This study examines the nature and factors influencing CSR spendings disclosed by Indonesian companies in the prospectuses for the period 2012 - 2019. Research data was hand-collected and analyzed using descriptive statistics, Pearson correlations, and multiple regressions. The findings show that most companies disclose CSR efforts; fewer companies reveal the amount spent on CSR activities. Among companies disclosing CSR spending, more spending is allocated in the years leading to the IPO date $(\mathrm{y})$ compared to previous years. Thus spending on $\mathrm{y}$ is relatively higher than $y-1$, follows by $y-2$ and $y-3$. CRS spending has a positive and significant relationship with company size. These findings are consistent across alternative model specifications. This study made an essential contribution to the CSR literature by providing Indonesia's first empirical evidence on the CSR expenditure in IPO prospectuses.
\end{abstract}

Keywords: Corporate Social Responsibility Disclosure; Corporate Social Responsibility Spending; Initial Public Offering; Prospectuses; Resource Dependency Theory.

\section{INTRODUCTION}

In the last few years, the Indonesia Stock Exchange (IDX) has listed many companies in various sectors. In 2018 alone, Indonesia's IPO reached 58 companies representing $4 \%$ of the total 1,384 new global IPO issuers, placing Indonesia in the 10th Global Initial Public Offering (IPO) in 2018 (KB Bukopin, 2019; Oke Finance, 2019). Likewise, in 2019 and 2020, respectively recorded 55 and 51 companies on the IDX. This trend is likely due to the ease of issuance provided by the Financial Services Authority (OJK) to boost Indonesia's economic growth through the expansion of public companies (OJK., 2016). However, this positive intention may have compromised investor protection, which is another main objective of the OJK. The convenience provided by the OJK for issuing companies, among others, is the lack of detailed requirements about what 
information and how a company should provide certain information in its prospectus, which is essential for investors to better assess the company's risk and prospect. On the other hand, the IPO companies strive to attract large numbers of investors by informing many aspects of the company's prospects, including disclosing information about how committed the company is to build a good impact in society, for example, through Corporate Social Responsibility (CSR). As pointed out by Arenas-Parra and ÁlvarezOtero (2020) that companies that carry out IPOs have a higher level of information asymmetry because they have never been exposed to the capital market before. Thus, the informative value of CSR disclosure is higher to potential investors because it can be used for company valuation purposes, which in turn can support the success of the IPO.

Efforts to attract potential investors also seem to impact the company's post-listing market performance positively. Huang, Xiang, Liu, Su, and Qiu (2019) examine CSR disclosure on 1,238 prospectuses of companies that conducted IPOs in China in 2010-2016. The sample of this study was divided into two indexes, namely an index to measure corporate social performance (CSP) and company environmental performance (CEP). They find that CSP disclosure has a significant positive relationship with post-IPO market performance. Interestingly, better CSP disclosure was associated with higher returns on post-IPO ownership but only among companies that did not disclose environmental expenditures.

In contrast, this association did not apply to companies that made environmental expenditures. These mixed results of the above study indicate that investors tend to support CSR disclosure but avoid companies with environmental spending. This can eliminate the company's motivation to disclose CSR expenditures.

Other studies suggest that while many companies seek to adopt corporate responsibility and sustainability as part of their strategic operations (Russo-Spena, Tregua, \& De Chiara, 2018), a number of other studies have reported the interrelationship between strategy, reporting, and communication in dealing with CSR disclosure (McElhaney, 2009; Pérez-López, Moreno-Romero, \& Barkemeyer, 2015).

However, a large number of researchers have also documented that CSR activities are essentially motivated by companies' strategic efforts (Dawkins \& Fraas, 2013; Engman \& Hagström, 2017; Ogola \& Dreer, 2012; Piacentini, MacFadyen, \& Eadie, 2000) or adherence to societal pressure and legislations (Abhishek Mukherjee \& Bird, 2016; Visser, 2012) and therefore not entirely to become good corporate citizens. In the IPO prospectus, this type of personification strategy attempts to conduct a successful IPO and gives investors the wrong signal about their true CSR commitments. Therefore, looking at CSR disclosures by companies alone does not tell the whole story because companies might use elaborative descriptions in their prospectus for their limited CSR activities. We argue that company disclosures about CSR spending, which describe the amount of money spent on CSR activities, are more genuine than the CSR item itself. This is because CSR activities can still be described broadly for the relatively few disclosure items, thus portraying the company's extensive list of CSR activities. However, for CSR spending, the amount cannot be disguised by the description.

Michelon, Pilonato, and Ricceri (2015) reinforce the existence of a symbolic CSR disclosure. They study three CSR reporting practices: stand-alone reporting, assurance, and reporting guidelines. They question whether the practice results from a substantive approach to improving the quality of the duty of accountability to stakeholders or simply 
as a symbolic act to portray the company as genuinely committed to CSR. This study indicates that, in general, this practice does not provide better quality information, indicating symbolic use of CSR practices.

Therefore, in this study, we use CSR Spending to investigate companies' commitment to social endeavors during their IPO process. Our initial investigations began while conducting previous research in this area. We found that CSR spending research is rare, especially in the Indonesian context, let alone in the IPO prospectus. This is the gap that this research seeks to fill.

Thus, this study aims to examine the nature and factors influencing CSR Spending disclosed by Indonesian companies in the prospectus for the period 2012-2019. The sample of this study consists of all companies carrying out IPOs during the study period whose shares are still actively traded on IDX. 253 prospectuses were selected from 2012 to 2019 as the study sample. The study period was chosen because empirical activities were carried out in 2020, where 2019 was the last year for which data was available. The beginning of the study period was chosen in 2012 because that Year was a new chapter for the Indonesian capital market where the Financial Services Authority (OJK) officially became the capital market regulator in Indonesia based on Regulation Number 21 of 2011. The research data are collected from the relevant prospectuses using content analysis and then analyzed statistically using Stata I.C. 15 application for descriptive statistics, Pearson correlations, and multiple regressions.

Most companies disclose CSR efforts at a relatively low level, but fewer companies disclose the amount spent on CSR activities. Of the companies that disclosed CSR expenditures, more spending was allocated in the years leading up to the IPO date (y) than in previous years, so spending on $y-1$ was relatively higher, followed by $y-2$ and $y-3$. We also find that CRS Spending has a positive and significant relationship with firm size. We conducted three additional models as sensitivity tests to the main test, and firm size consistently showed positive and significant results in all three models. Thus, firm size is a driver of CSR spending in our sample firms. This result is robust for alternative specifications. We also find that firm age and auditor reputation have a negative relationship with CSR spending. However, these results do not hold to alternative specifications.

This study adds several important contributions to the CSR debate. First, it provides Indonesia's first empirical evidence on disclosure of CSR spending in the IPO prospectus. Second, it provides longitudinal empirical insights on the main factors influencing voluntary disclosure of CSR expenditures in the Indonesian prospectus. Third, this study provides future direction for Indonesian academics, regulators, and professional bodies to assess whether to emphasize CSR reporting practices, particularly in CSR spending and research.

The rest of this paper is organized as follows. Section 2 presents a literature review concerning Initial Public Offering and CSR regulations in Indonesia; the existing CSR Spending literature both internationally and in Indonesia. Finally, we develop a hypothesis based on the discussion. Section 3 describes the research design regarding sample selection, research variables, data collection, and empirical models. The results of the study and discussion are presented in Section 4 and Section 5. Finally, section 6 summarizes the study's main findings and discusses their limitations and implications for future studies and the world of practice. 


\section{HYPOTHESES DEVELOPMENT}

Companies carrying out IPOs must issue prospectuses to attract investors to invest in their companies during the initial offering. The offering's success is usually characterized by the company's initial stock being over-subscribed, leading to the highest price range offered. For that, a company has an incentive to successfully carry out an IPO. Therefore, it is in the company's best interest to impress potential investors with a detailed description of the company in the prospectus. A well-prepared prospectus usually outlines mandatory and voluntary information. Therefore, it is prevalent for companies to voluntarily disclose their CRS activities, also known as CSR performance, and information regarding the amount of money spent on these activities, known as CSR spending or CSR expenditure.

In Indonesia, the disclosure of CSR performance and CSR spending in the prospectus are also still voluntary because there are no regulations governing companies to disclose this information during our study period. OJK only encourages companies to disclose CSR activities at least three years before the IPO date in the prospectus guideline. Still, no detailed explanation is given about how and what items should be disclosed (Zuraida \& Sugianto, 2019). The Financial Services Authority regulation number 9 / POJK.04/2017 -concerning form and content of brief prospectus and prospectus for the general offering of equity securities- mentions in the corporate governance section the issuing company is required to disclose a description of social and environmental responsibility (if any). In other words, the company is not obliged to carry out CSR activities, but only if they do, then they must disclose (OJK., 2017). Thus, in this regulation, besides there are no guidelines on what items and how to disclose CSR in the prospectus, there is also no mention of the obligation to disclose company spending for CSR. Therefore, every CSR item that is disclosed is fully left to the company's discretion.

Given that disclosure of CSR-related information in the IPO is submitted to the individual company policy, the disclosures can vary widely between companies. This is understandable because each company must have its own strategy for a successful IPOfor example, which potential investors they want to attract- so they prioritize the drivers they value as more important.

With the absence of detailed guidelines regarding CSR disclosure in the prospectus of companies conducting IPOs in Indonesia from 2012 to 2019, we are interested in examining what makes companies disclose such information and what factors are related to CSR performance and expenditures in those companies. In particular, we want to investigate the relationship between selected company attributes and the disclosures of CSR performance and spending.

Resource Dependency Theory (RDT) considers that companies have a dependency on their critical resources. The degree of this dependence determines the company's actions and decisions (Adomako \& Nguyen, 2020; Frynas \& Yamahaki, 2016). This theory considers that the social context is an important factor that determines the success of a company. Therefore companies need to develop certain strategies to increase their independence. Adopting the RDT concept, CSR spending is manifested by the attributes of the company.

Previous studies have linked that the following company attributes are related to CSR activities: age, size, industry, underwriter reputation, leverage, and profit. Prior 
studies have suggested that Company age (Derwall, 2007); size (S. M. Ali \& Isa, 2018; Baluja, 2017; Jain \& Mishra, 2011; A. Russo \& Perrini, 2010; Verma \& Jain, 2019; Zuraida \& Sugianto, 2019); Industry (M. V. Russo \& Fouts, 1997); Underwriter (Arenas-Parra \& Álvarez-Otero, 2020); Leverage (S. M. Ali \& Isa, 2018; Arora \& Soni, 2017); profit (Baluja, 2017; Derwall, 2007; Zuraida \& Sugianto, 2019) are associated with company CSR disclosures. Furthermore, W. Ali, Frynas, and Mahmood (2017) who reviewed 76 empirical research articles from developed and developing countries confirmed that CSR disclosure is associated with company characteristics such as company size, profitability, and corporate governance.

Thus studies that focus on CSR spending, such as Petrenko, Aime, Ridge, and Hill (2016), have controlled ROA to consider the likelihood that CSR spending is influenced by company profitability. Abhishek Mukherjee and Bird (2016) stated that CSR expenditure is also influenced by company characteristics, such as size (A. Russo \& Perrini, 2010 industry (M. V. Russo \& Fouts, 1997), geographic location (Bird, D. Hall, Momentè, \& Reggiani, 2007), age, ownership (Oh, Chang, \& Martynov, 2011) and peer pressure (Malik, Al Mamun, \& Amin, 2019).

However, the approaches to CSR disclosure appear to differ between jurisdictions. In Indonesia, companies or non-profit organizations are often seen carrying out fundraising activities to collect funds from the community or their employees. The proceeds then go to certain parties such as flood victims. However, donations like this are made by exposing the name of the company when delivering the aid.

In line with the above arguments, Smith (2018) reports a study conducted by the economic consulting firm EPG. They found that the approach to CSR by U.S. and U.K. companies is very different, but CSR spending in the two countries is relatively the same, where only a handful of companies do so. In the U.S., however, 71 percent of U.S. \$11.95 billion in US CSR spending is in the form of donations in kind, such as free medicine for health care programs or free software to universities; this is followed by a cash contribution of 16 percent and the remainder are in the form of employee engagement and fundraising. Meanwhile, in the U.K., contributions in the form of goods and services accounted for 46 percent of total CSR activities valued at $\$ 3.25$ billion, followed by volunteering and employee fundraising at 34 percent and cash contributions by 20 percent. In general, companies tend to direct their CSR activities to fields that they are familiar with. Perhaps this is why CSR spending on health is far greater than spending on education. This report further demonstrates that CSR spending is contextual. We, therefore, hypothesize that:

$\mathrm{H}_{1}$ : The amount of CSR spending is positively associated with the following company attributes; age, size, industry, underwriter reputation, leverage, and profit.

We further argue that the company's response to CSR is also time-variant. In fact, corporate social responsibility has changed the way businesses are operated in society, from the absence of responsibility other than to shareholders to increased understanding, acceptance, and even an obligation to carry out and disclose social responsibility activities (Bhaduri \& Selarka, 2016). This notion is also supported by Ioannou Serafeim, a Harvard Business School professor who focuses on sustainability research in Smith (2018), who states that investors' reactions to CSR have changed over time. In the 1990s, the response to CSR activities was still mainly negative because CSR spending was considered a waste 
of company money on activities that were not related to shareholder values. In recent years, these negative impressions have started to become neutral. Investors increasingly see environmental, social, and governance factors as the leading indicators in assessing investment decisions, especially for long-term investments.

India is even one step ahead in this regard compared to other countries. India is perhaps one of the earliest countries that have made CSR spending mandatory through the Companies Act, 2013 where companies of a certain size must spend at least two percent of their three-year average net income on CSR activities (Bhattacharyya \& Rahman, 2019; Desai, Viswanath, \& Tripathy, 2015; Mohanty, 2014; Abhishek Mukherjee \& Bird, 2016; Arup Mukherjee \& Chaturvedi, 2013; Sharma, 2013; Singh \& Verma, 2014; Varottil, 2018; Verma \& Jain, 2019).

However, suppose the company's approach to CSR spending is only strategic and not to be a good corporate citizen. In that case, even when CSR spending is mandatory, the company will still try to find regulatory loopholes to not comply with government regulations. Compliance with the rules also becomes questionable if CSR expenditures do not positively impact the company's financial performance. As reported in this study by Bhattacharyya and Rahman (2019), reviewing the performance of public and private sector companies in India after implementing mandatory corporate social responsibility (CSR) spending, they find that the performance of public companies is lower. The performance of private firms has no difference with companies that do not implement mandatory CSR spending. Therefore, the response to these regulations is considered an imposition and disrupts profitability and share prices (Desai et al., 2015). This can make companies reluctant to spend more on CSR than on just the bare minimum to comply with the regulation. Thus, mandatory CSR spending can result in moral hazard, which can reduce overall CSR spending if the only motivation for CSR spending is to comply with regulation and as part of company strategy alone.

Tendolkar (2019) reports that Indian companies started making CSR spending after mandatory CSR spending, but still at a less generous level, with the spending curve from 2015 to 2018 hovering around the $2 \%$ benchmark of its spending going to education and health care sectors. This further confirms our argument that if CSR spending is mandatory, companies will comply with it as part of their strategy to gain legitimacy. Still, their CSR expenditure is only at the level of meeting regulatory requirements.

Ogola and Dreer (2012) study the relationship between the Cola-Cola market share in traditional soft drink markets and new markets to examine the correlation between spending on CSR and market share in Kenya and Egypt. They found when the market share was low and spending was low, when the market share is at medium size, the expenditure is higher; when the market share is higher, the expenditure is lower. It suggests that CSR spending is only intended to win the market share competition in the middle-sized market. This further confirms that CSR spending is strategic.

With a strong indication from previous studies that companies carrying out CSR activities are highly influenced by their strategic objectives rather than the desire to be good corporate citizens- although there has not been enough previous research examining the reasons for companies to spend on CSR- we consider that the company's motivation to spend on CSR activities is the same as the company's motivation for other CSR activities that are strategic driven. So the company will disclose more CSR spending in the 
period leading up to the IPO to show as if the company is paying great attention to sustainable practices; thus, we posit that:

$\mathrm{H}_{2}$ : The amount of CSR spending is higher in the years close to IPO years.

\section{METHOD, DATA, AND ANALYSIS}

\section{Sample}

The study sample consists of 253 companies, namely all companies that issued IPO prospectuses during the study period from 2012-2019. Initially, 257 companies conducted IPOs during the study period, but four companies were removed from the sample because three of them were delisted and no longer active on the stock market, while one company was a corporate bond, which is outside the focus of our research. The list of sample companies is shown in table 1.

Table 1. The Number of Research Samples

\begin{tabular}{cccc}
\hline IPO Year & $\begin{array}{c}\text { Number of Prospectuses } \\
\text { used in the analysis }\end{array}$ & $\begin{array}{c}\text { Number of Prospectuses } \\
\text { issued in the respective } \\
\text { year }\end{array}$ & $\begin{array}{c}\text { Excluded from the } \\
\text { research sample }\end{array}$ \\
\hline 2012 & 22 & 22 & 2 delisted companies \\
2013 & 28 & 30 & 1 delisted company \\
2014 & 23 & 24 & \\
2015 & 16 & 16 & \\
2016 & 15 & 15 & 1 corporate bond \\
2017 & 37 & 37 & 4 \\
2018 & 57 & 58 & \\
2019 & 55 & 55 & \\
\hline Total & 253 & 257 & \\
\hline
\end{tabular}

\section{Variables and Measurements}

This section explains the method used to investigate the disclosure of CSR spending disclosed in the Initial Public Offering (IPO) prospectuses of Indonesian companies for 2012 - 2019 and its relationship with company attributes. Existing empirical literature shows that several company attributes are associated with CSR performance, among others are firm age (Derwall, 2007), size (Albuquerque, Durnev, \& Koskinen, 2013; Andersen, 2011; Derwall, 2007; Goss \& Roberts, 2011), leverage (Andersen, 2011; Goss \& Roberts, 2011; McWilliams \& Siegel, 2000; Nollet, Filis, \& Mitrokostas, 2016) and profitability (Goss \& Roberts, 2011; Li \& Zhang, 2010; Nollet et al., 2016).

In this study, two constructs of non-financial variables, namely the underwriter's reputation (Feng, Chen, \& Tseng) and auditor reputation, are also included in the regression model. The inclusion of these two variables is that reputable underwriters tend to place stricter rules for disclosure in a prospectus, consisting of all information needed, such as CSR spending. Likewise, adding a respected auditor in the regression model is because companies that are willing to pay high for reputable auditors are expected to have the tendency to spend extra on CSR activities to gain a positive corporate image and legitimacy.

The level of CSR spending (CSRS) is measured as the total amount spent by IPO companies from three financial years before IPO year and the IPO year. Corporate attributes are measured by company size, the book value of total assets (Size); company 
Age, the length of time of company's establishment from the date of establishment until IPO date (Age); Leverage, the debt-to-equity ratio (Lev); Profit, the total profit earned by IPO companies from three financial years prior to IPO year (Profit); Underwriter reputation, the 50 most active brokerage houses in total value that are published on Monthly Statistics April 2018 by IDX. Dummy variable applied to measure the underwriter reputation by scoring 1 if the underwriter on the chosen list and 0 if it is not (Underwriter); Auditor reputation, a dummy variable denotes 1 if part of big four accounting firms, and 0 otherwise (Auditor) and Industry, coded 1 to 9 based on the alphabetical order of companies industrial names based on the Jakarta Stock Industrial Classification (JASICA). However, it should be noted that at the time of compiling this text, the Indonesia Stock Exchange (IDX) was in the process of replacing JASICA with the IDX Industrial Classification (IDX-IC), which was effective starting January 25, 2021. However, during the transition period, namely the first three months since in operation of IDX -I.C., both JASICA and IDX-IC are used simultaneously. JASICA classifies businesses into 9 sectors with 56 sub-sectors, while the IDX-IC uses the classification of 12 sectors with 35 sub-sectors, 69 industries, and 130 sub-sectors (Hartomo, 2021; Newsy Today, 2021). Considering our research period is between 2012 and 2019, JASICA is used in this study. Other than data for underwriter and auditor reputations collected from IDX, the research data was hand-collected from the IPO prospectus.

\section{Analysis}

Research data were analyzed using Stata I.C. 15 for descriptive statistics, Pearson correlation, and multiple regression. To obtain unbiased estimates from the OLS regression, we performed the following classical assumptions test. First, we perform a normality test, and the histogram shows that our data is skewed. Second, we also perform a Multicollinearity test, and all of our Vif values are around 1 or far below 10. Besides, our Pearson correlation coefficients are also below 0.7 . Therefore we conclude that we have no multicollinearity problem in our data. For the Heteroscedasticity test, we performed Breusch-Pagan / Cook-Weisberg test. We find that the Prob $>$ chi2 $=0.5519$ since the value is bigger than $5 \%$, we conclude that there is no heteroscedasticity problem. Fourth, because our data is in the form of a time series, an autocorrelation test was carried out using the Durbin-Watson statistic. The value is 2.0353, with a smaller critical value between 1,651 and 1,765. It is concluded that autocorrelation is detected in the sample. Thus, from the four classical assumption tests, normality and autocorrelation are problematic in our data set. To overcome these problems, the following two methods are used. First, we use robust regression to treat both normalities- "Robust regression is an alternative to least squares regression when data are contaminated with outliers or influential observations" (UCLA, 2021)- and autocorrelation issues (Jochumzen, 2017). Second, we use transformed data for regressions to further the threat of normality issue as shown in Models 2 - Model 4-the regression model in equation (1).

$$
\begin{aligned}
& \text { CSRS }=a+\beta_{1} \text { Size }_{1}+\beta_{2} \text { Age }_{2}+\beta_{3} \text { Profit }_{3}+\beta_{4} \text { Lev }_{4}+\beta_{5} \text { Auditor }_{5}+\beta_{6} \text { Underwriter }_{6}+\beta_{7} \text { Industry7 }+\mathrm{e} \\
& \text { CSRS }=\text { CSR expenses, the amount of money the company spends on CSR } \\
& \text { activities, this data is available in the company's prospectus. } \\
& \text { Size }=\text { Company size, measured by the book value of total assets } \\
& \text { Age } \quad=\text { Age of the company, measured by the year since its establishment until } \\
& \text { the Year of IPO } \\
& \text { Profit }=\text { Total company profit since three financial years prior to IPO year. }
\end{aligned}
$$




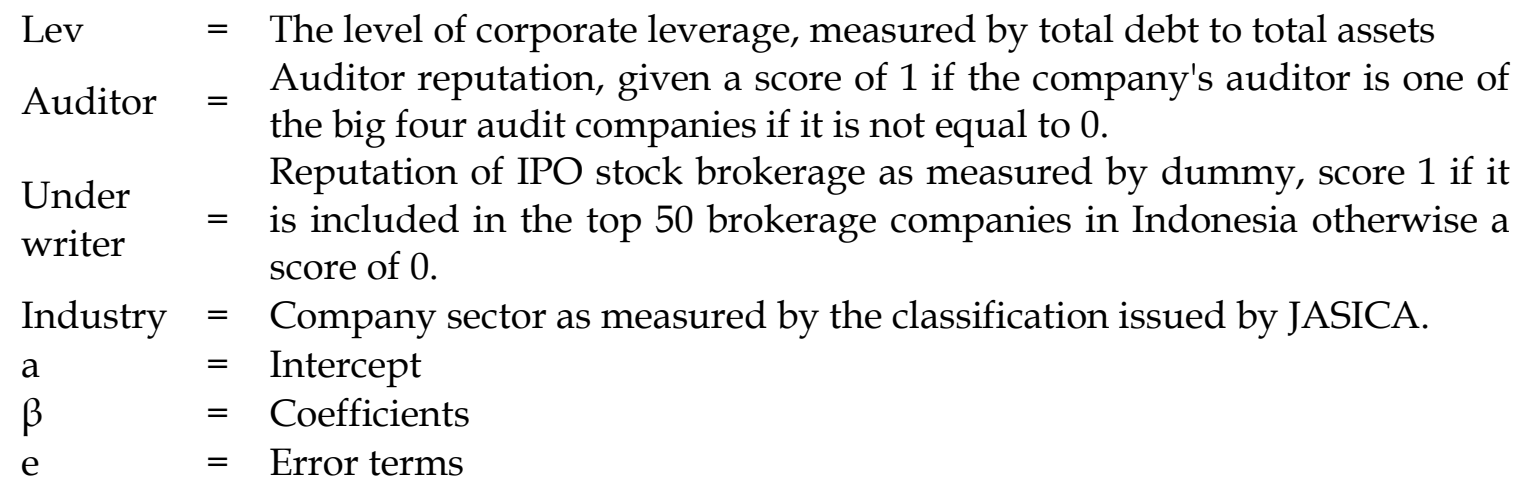

\section{RESULTS}

\section{Descriptive Statistics}

This segment provides descriptive statistics to explain the nature of disclosure of CSR expenditures by our sample firms. Our sample companies consisted of 253 IPO companies. Only 110 companies (43.47\%) included CSR in their prospectus at least once, while the rest did not. Table 2 shows the number of prospectuses classified into two groups of companies based on their total assets (as a measure of company size): Large companies for total assets above the mean value and small companies for those with total assets below the mean value. Table 2 shows the number of large companies as many as 46 companies (18.18\%) and small companies as many as $207(81.81 \%)$ from a total of 253 companies. Of the large companies, 19 companies (7.51\%) disclosed CSR Spending in their prospectuses, while in the small companies group, there were 59 companies (23.32\%) disclosing CSR spending. In terms of CSR expenditure, large companies only spend IDR 192,370,822 (32.75\%) compared to small companies that spend IDR 394,999,015 $(67.24 \%)$ out of a total of IDR 587,369,847 -this amount in thousand Rupiah-. However, the average expenditure for each large company is $6.66 \%$ compared to small companies, which is only $3.2 \%$ of the total CSR spending in this analysis.

Table 2. Number of prospectuses by company size

\begin{tabular}{|c|c|c|c|c|}
\hline Year & $\begin{array}{l}\text { Number of a } \\
\text { prospectus in the } \\
\text { sample }\end{array}$ & $\begin{array}{l}\text { Number of } \\
\text { prospectuses } \\
\text { disclosing CSR } \\
\text { Spending }\end{array}$ & $\begin{array}{l}\text { Amount spent } \\
\text { (Thousand) }\end{array}$ & $\begin{array}{l}\text { Per individual } \\
\text { company }\end{array}$ \\
\hline Large & $46(18.18 \%)$ & $19(7.51 \%)$ & $\begin{array}{r}\text { Rp.192.370.827 } \\
(32.75 \%)\end{array}$ & $\begin{array}{r}0,0668392376 \\
(6.68 \%)\end{array}$ \\
\hline Small & 207 (81.81\%) & $59(23.32 \%)$ & $\begin{array}{r}\text { Rp.394.999.015 } \\
(67.24 \%)\end{array}$ & $\begin{array}{r}0,0324873302 \\
(3.24 \%)\end{array}$ \\
\hline Total & 253 & 78 & Rp.587,369,847 & \\
\hline
\end{tabular}

Table 2 shows that of the 253 sample companies in the study, only 78 companies $(30.83 \%)$ disclosed their CSR expenditures in their prospectus. Table 3 shows that CSR expenditure is divided in the IPO year $(\mathrm{Y})$ at $41.32 \%$, and the remaining $59.19 \%$ is divided for the previous years, namely Y-1 at $19.80 \%, \mathrm{Y}-2$ at $32.03 \%$, and Y-3 at $7.35 \%$. This shows that the company strategically plans CSR expenditure before the IPO year and allocates more funds in the period close to the IPO date 
Table 3. Spending by IPO

\begin{tabular}{|c|c|c|c|c|c|c|}
\hline Description & $\begin{array}{c}\text { Total } \\
\text { spending } \\
\mathrm{Y}+(\mathrm{Y}-1)+ \\
+(\mathrm{Y}-2)+ \\
+(\mathrm{Y}-3)\end{array}$ & $\begin{array}{c}\text { Total } \\
\text { spending } \\
\text { excluding } \\
\text { IPO year } \\
(\mathrm{Y}-1)++(\mathrm{Y}- \\
2)++(\mathrm{Y}-3)\end{array}$ & $\mathbf{Y}$ & $(\mathrm{Y}-1)$ & $(\mathrm{Y}-2)$ & $(\mathrm{Y}-3)$ \\
\hline \multicolumn{7}{|l|}{ Amount } \\
\hline $\begin{array}{l}\text { (Thousand } \\
\text { Rupiah) }\end{array}$ & 587.369 .842 & 347.703 .188 & 242.719 .444 & 116.342 .387 & 188.173.153 & 43.187 .648 \\
\hline Percentage & $100 \%$ & $59.19 \%$ & $41.32 \%$ & $19.80 \%$ & $32.03 \%$ & $7.35 \%$ \\
\hline
\end{tabular}

Table 4. Number of prospectuses by year disclose CSR Spending

\begin{tabular}{cccc}
\hline Year & $\begin{array}{c}\text { Number of a } \\
\text { prospectus in the } \\
\text { sample }\end{array}$ & $\begin{array}{c}\text { Number of } \\
\text { prospectuses } \\
\text { disclosing CSR } \\
\text { spending }\end{array}$ & $\begin{array}{c}\text { Percentage of } \\
\text { prospectus disclosing } \\
\text { CSR spending by year }\end{array}$ \\
\hline 2012 & 22 & 12 & $15 \%$ \\
2012 & 28 & 11 & $14 \%$ \\
2013 & 23 & 13 & $17 \%$ \\
2014 & 16 & 10 & $13 \%$ \\
2015 & 15 & 5 & $6 \%$ \\
2016 & 37 & 8 & $10 \%$ \\
2017 & 57 & 14 & $18 \%$ \\
2019 & 55 & 5 & $6 \%$ \\
\hline Total & 253 & 78 & $100 \%$ \\
\hline
\end{tabular}

Table 4 shows in more detail the number of companies that disclose CSR expenditures in their prospectus by IPO year and Table 5 by industry. There is no concentration of disclosure of CSR expenditures in certain years or certain industries. This suggests that disclosure of CSR spending depends on the management policies of each IPO company and is not influenced by the encouragement of peers in the same industry or other annual trends. Table 6 shows the descriptive statistics for the variables used in this study. There are 253 observations for each variable, indicating no missing value. CSR expenditure, size (total assets), and profit are continuous variables with the mean value not exceeding four times the standard deviation indicating normally distributed data. The companies that carry out the IPO start from 0 to 64 years, and there is 1 company that is 0 years old and 2 companies that are 2 years old, and several other companies that are under 5 years old. It is interesting to learn that several newly established companies have been permitted to conduct IPOs. However, even older and more experienced companies did not show a better commitment to CSR spending. Auditor's reputation and underwriting reputation are dummy variables with a value of 1 or 0 . At the same time, industry is also a dummy variable even though it has 9 categories, but the order does not provide different values. The numbering is only for classification purposes. 
Table 5. Number of prospectuses by industry

\begin{tabular}{llll}
\hline \multicolumn{1}{c}{ Industry } & Industry_Code & No of Prospectus & $\begin{array}{c}\text { No of } \\
\text { Prospectus } \\
\text { with CSR } \\
\text { Spending }\end{array}$ \\
\hline Agriculture & 1 & 10 & 1 \\
Basic Industry and Chemical & 2 & 22 & 9 \\
Consumer Goods Industry & 3 & 21 & 7 \\
Finance & & 29 & 10 \\
Infrastructure, Utilities and Transportation & 4 & 38 & 12 \\
Infrastructure, Utilities and Transportation & 5 & 38 & 3 \\
Mining & 5 & 11 & 5 \\
Miscellaneous Industry & 6 & 15 & 10 \\
Property, Real Estate, and Building Construction & 8 & 35 & 21 \\
Trade, Service, and Investment & 7 & 72 & 78 \\
Total & 9 & 253 & \\
\hline
\end{tabular}

Table 6. Number of prospectuses disclosing CSR spending

\begin{tabular}{lrrrrr}
\hline \multicolumn{1}{c}{ Variable } & $\mathbf{N}$ & Mean & $\begin{array}{c}\text { Standard } \\
\text { Deviation }\end{array}$ & Minimum & Maximum \\
\hline CSR Spending & 253 & 2321620 & $1.39 \mathrm{e}+07$ & $0^{*}$ & $136.021 .000^{*}$ \\
Size & 253 & 2460688 & $1.30 \mathrm{e}+07$ & $-63.371^{*}$ & $202.608 .014^{*}$ \\
Age & 253 & 17.55336 & 12.85612 & 0 & 64 \\
Profit & 253 & 29334.3 & 188583.1 & $-487.010^{*}$ & $2.730 .632^{*}$ \\
Lev & 253 & 0.523986 & 0.2621778 & -0.758249 & 0.9826 \\
Auditor & 253 & 0.1541502 & 0.3618084 & 0 & 1 \\
Underwriter & 253 & 0.7391304 & 0.4399793 & 0 & 1 \\
Industry & 253 & 6.01581 & 2.633677 & 1 & 9 \\
\hline
\end{tabular}

*Thousand Rupiah

Table 7 shows the Pearson correlation coefficients with an asterisk indicating a significant relationship. Firm size is positively related to CSR expenditure; profit is positively associated with the company's age; auditor reputation is positively associated with leverage; underwriter reputation is negatively associated with profit, and industry is negatively related to profit and auditor reputation. All of those relationships are significant, but there is no relationship among our variables that is stronger than 0.7, indicating that there is no multicollinearity between variables. 


\section{Pearson correlations}

Table 7. Pearson Correlation Coefficient

\begin{tabular}{|c|c|c|c|c|c|c|c|c|}
\hline & $\begin{array}{l}\text { CSR } \\
\text { Spending }\end{array}$ & Size & Age & Profit & Lev & Auditor & Underwriter & Industry \\
\hline $\begin{array}{l}\text { CSR } \\
\text { Spending }\end{array}$ & 1.0000 & & & & & & & \\
\hline \multirow[t]{2}{*}{ Size } & $\begin{array}{l}0.5917^{*} \\
(0.000)\end{array}$ & 1.0000 & & & & & & \\
\hline & $\begin{array}{l}\text { CSR } \\
\text { Spending }\end{array}$ & Size & Age & Profit & Lev & Auditor & Underwriter & Industry \\
\hline Age & $\begin{array}{l}-0.0296 \\
(0.6394)\end{array}$ & $\begin{array}{l}0.1132 \\
(0.0722)\end{array}$ & 1.0000 & & & & & \\
\hline Age & $\begin{array}{l}-0.0296 \\
(0.6394)\end{array}$ & $\begin{array}{l}0.1132 \\
(0.0722)\end{array}$ & 1.0000 & & & & & \\
\hline Profit & $\begin{array}{l}0.0436 \\
(0.4902)\end{array}$ & $\begin{array}{l}0.1141 \\
(0.0700)\end{array}$ & $\begin{array}{c}0.1537^{*} \\
(0.0144)\end{array}$ & 1.0000 & & & & \\
\hline Lev & $\begin{array}{l}0.0587 \\
(0.3526)\end{array}$ & $\begin{array}{l}0.0352 \\
(0.5776)\end{array}$ & $\begin{array}{l}0.0172 \\
(0.7851)\end{array}$ & $\begin{array}{l}-0.0184 \\
(0.7709)\end{array}$ & 1.0000 & & & \\
\hline Auditor & $\begin{array}{l}-0.0260 \\
(0.6804)\end{array}$ & $\begin{array}{l}0.0654 \\
(0.3000)\end{array}$ & $\begin{array}{l}0.1172 \\
(0.0626)\end{array}$ & $\begin{array}{l}-0.0256 \\
(0.6852)\end{array}$ & $\begin{array}{c}0.1584^{*} \\
(0.0117)\end{array}$ & 1.0000 & & \\
\hline Underwriter & $\begin{array}{l}-0.0562 \\
(0.3732)\end{array}$ & $\begin{array}{l}-0.0860 \\
(0.1726)\end{array}$ & $\begin{array}{l}-0.0740 \\
(0.2409)\end{array}$ & $\begin{array}{l}-0.1501^{*} \\
(0.0169)\end{array}$ & $\begin{array}{l}-0.0102 \\
(0.8718)\end{array}$ & $\begin{array}{c}0.0293 \\
(0.6432)\end{array}$ & 1.0000 & \\
\hline Industry & $\begin{array}{l}0.0073 \\
(0.9076)\end{array}$ & $\begin{array}{l}-0.0577 \\
(0.3606)\end{array}$ & $\begin{array}{l}- \\
0.2770^{*} \\
(0.0000)\end{array}$ & $\begin{array}{l}-0.1368^{*} \\
(0.0296)\end{array}$ & $\begin{array}{l}-0.0432 \\
(0.4939)\end{array}$ & $\begin{array}{l}-0.1525^{*} \\
(0.0152)\end{array}$ & $\begin{array}{l}0.0241 \\
(0.7026)\end{array}$ & 1.0000 \\
\hline
\end{tabular}

Table 8 shows the empirical results of this study, the main test (model 1), presented with three sensitivity tests (Model 2, Model 3 \& Model4). Model 1 shows the main test results using Ordinary Least Squares (OLS) regression with a robust option. We find that size has a positive and significant relationship with CSR spending while age and auditor reputation have negative and significant relationships with CSR spending. This model has an adjusted $\mathrm{R}^{2}$ of $0.34705769(34.70 \%)$ with 253 observations. We retest this model after performing variable transformation using log 10 on continuous variables, i.e., size, age, profit, and CSR spending.

The results are presented in model 2. We find the only size that has a positive and significant relationship with CSR spending. At the same time, there are no other variables that are significantly associated with CSR spending in this model. This second test was run on 253 observations and return adjusted $R^{2}$ at 05906951 (5.90\%). We also perform two other regressions by dividing the study sample into two groups consisting of large and small company groups. We again find that firm size is significantly and positively related to CSR spending in these two models, namely model 3 for large firms and model 4 for small firms. We also find that underwriting reputation is also associated with CSR spending in model 3. However, no other variable other than firm size consistently has a positive and significant relationship with CSR spending in our four regression models. 


\section{Empirical findings}

Table 8. Regression results and sensitivity tests

\begin{tabular}{|c|c|c|c|c|c|c|c|c|}
\hline \multirow[t]{3}{*}{ Variable(s) } & \multicolumn{2}{|c|}{ Main Test } & \multicolumn{6}{|c|}{ Sensitivity Tests } \\
\hline & \multicolumn{2}{|c|}{$\begin{array}{l}\text { OLS Regression } \\
\text { with Robust } \\
\text { Option } \\
\text { (Model 1) }\end{array}$} & \multicolumn{2}{|c|}{$\begin{array}{l}\text { OLS Regression } \\
\text { with Robust } \\
\text { Option with } \\
\text { variable } \\
\text { transformation } \\
\text { (Model 2) }\end{array}$} & \multicolumn{2}{|c|}{$\begin{array}{l}\text { OLS Regression } \\
\text { with Robust } \\
\text { Option with } \\
\quad \text { variable } \\
\text { transformation- } \\
\text { large companies } \\
\text { (Model 3) }\end{array}$} & \multicolumn{2}{|c|}{$\begin{array}{c}\text { OLS Regression } \\
\text { with Robust } \\
\text { Option with } \\
\quad \text { variable } \\
\text { transformation- } \\
\text { small companies } \\
\quad \text { (Model 4) }\end{array}$} \\
\hline & $\begin{array}{c}\text { Estimates } \\
(p \text { value })\end{array}$ & $\begin{array}{c}t- \\
\text { stat. }\end{array}$ & $\begin{array}{l}\text { Estimates } \\
(p \text { value })\end{array}$ & $\begin{array}{c}t- \\
\text { stat. }\end{array}$ & $\begin{array}{c}\text { Estimates } \\
\text { ( } p \text { value })\end{array}$ & $\begin{array}{c}t- \\
\text { stat. }\end{array}$ & $\begin{array}{c}\text { Estimates } \\
\text { (p value })\end{array}$ & $\begin{array}{c}t- \\
\text { stat. }\end{array}$ \\
\hline Size & $\begin{array}{r}.646536^{*} \\
(0.000)\end{array}$ & 28.83 & $\begin{array}{r}.8199065^{*} \\
(0.001)\end{array}$ & 3.46 & $\begin{array}{r}4.386406^{*} \\
(0.000)\end{array}$ & 5.31 & $\begin{array}{r}.6152489^{*} \\
(0.006)\end{array}$ & 2.78 \\
\hline Age & $\begin{array}{r}-95366.8^{*} \\
(0.012)\end{array}$ & -2.54 & $\begin{array}{r}.3224898 \\
(0.497)\end{array}$ & 0.68 & $\begin{array}{r}0.8944749 \\
(0.513)\end{array}$ & 0.66 & $\begin{array}{r}.0712073 \\
(0.887)\end{array}$ & 0.14 \\
\hline Profit & $\begin{array}{r}-.9699422 \\
(0.112)\end{array}$ & -1.59 & $\begin{array}{r}-.145851 \\
(0.058)\end{array}$ & -1.91 & $\begin{array}{r}-0.2399311 \\
(0.191)\end{array}$ & -1.33 & $\begin{array}{r}-.1558112 \\
(0.062)\end{array}$ & -1.88 \\
\hline Lev & $\begin{array}{r}2603663 \\
(0.249)\end{array}$ & 1.15 & $\begin{array}{r}.730001 \\
(0.254)\end{array}$ & 1.14 & $\begin{array}{r}2.520945 \\
(0.184)\end{array}$ & -1.35 & $\begin{array}{r}.7118367 \\
(0.287)\end{array}$ & 1.07 \\
\hline Auditor & $\begin{array}{r}-2375933^{*} \\
(0.025)\end{array}$ & -2.26 & $\begin{array}{r}-.4747448 \\
(0.347)\end{array}$ & -0.94 & $\begin{array}{r}-1.467828 \\
(0.106)\end{array}$ & -1.65 & $\begin{array}{r}-.1238347 \\
(0.848)\end{array}$ & -0.19 \\
\hline Underwriter & $\begin{array}{r}-367039.9 \\
(0.819)\end{array}$ & -0.23 & $\begin{array}{r}.3233998 \\
(0.388)\end{array}$ & 0.86 & $\begin{array}{r}2.277504^{*} \\
(0.018)\end{array}$ & 2.48 & $\begin{array}{r}.0117696 \\
(0.977)\end{array}$ & 0.03 \\
\hline Industry & $\begin{array}{r}48201.45 \\
(0.808)\end{array}$ & 0.24 & $\begin{array}{r}.0018033 \\
(0.978)\end{array}$ & 0.03 & $\begin{array}{r}.1470163 \\
(0.421)\end{array}$ & 0.81 & $\begin{array}{r}-.0374577 \\
(0.595)\end{array}$ & -0.53 \\
\hline Intercept & $\begin{array}{r}1413888 \\
(0.449) \\
\end{array}$ & 0.076 & $\begin{array}{r}-3.650981^{*} \\
(0.010) \\
\end{array}$ & -2.60 & $\begin{array}{r}-31.16333^{*} \\
(0.000)\end{array}$ & -5.92 & $\begin{array}{r}-1.801506 \\
(0.182)\end{array}$ & -1.34 \\
\hline $\mathrm{R}^{2}$ & 0.3652 & & 0.0852 & & 0.35264923 & & 0.0571 & \\
\hline Adj. $R^{2}$ & 0.34705769 & & .05906951 & & 0.23340041 & & 0.02392856 & \\
\hline $\begin{array}{l}\mathrm{F} \\
\text { Prob }>\mathrm{F} \\
\mathrm{N}\end{array}$ & $\begin{array}{r}127.17 \\
(0.0000) \\
253\end{array}$ & & $\begin{array}{r}3.39 \\
(0.0018) \\
253\end{array}$ & & $\begin{array}{r}8.07 \\
(0.0000) \\
46\end{array}$ & & $\begin{array}{r}2.35 \\
(0.0250) \\
207\end{array}$ & \\
\hline
\end{tabular}

Robust standard errors in parentheses: $* * * p<0.01,{ }^{* *} \mathrm{p}<0.05,{ }^{*} \mathrm{p}<0.1$

\section{DISCUSSION}

Several important factors can be interpreted from the above analysis. First, only 110 companies $(43.47 \%)$ that conducted IPOs mentioned CSR in their prospectuses, and only 78 companies $(30.83 \%)$ that conducted IPOs disclose their CSR expenditures. This indicates that the concept of CSR is still relatively unnoticed by issuing companies even though there is a suggestion from the OJK in the prospectus guidelines.

This is in accordance with previous research, which suggests that companies with CSR expenditures have two objectives: strategic (Dawkins \& Fraas, 2013; Engman \& Hagström, 2017; Ogola \& Dreer, 2012; Piacentini et al., 2000) and compliance goals (Tendolkar, 2019). So if these two motivations are the main reasons companies are involved with CSR, it seems that CSR commitment overtime will not be much different without a binding regulation on CSR spending. However, at the time of writing this manuscript, the Indonesian government has put some extra emphasis on corporate 
sustainability practices, such as by issuing the IDX ESG (Environmental, Social, Governance) Leaders index in December 2020. Previously in 2017, the Financial Services Authority also introduced Rule No. 51/POJK.03/2017, a requirement for these companies to implement sustainable finance: Financial services providers (including banking, financing, insurance, pension funds, and capital market entities), issuers, and public companies (Darmawan \& Setiono, 2020). Although this regulation has not been shown to significantly improve CSR practices in our sample companies, in the long term, with constant awareness, government regulations, there is a better chance for public companies to commit to CSR practices and disclosures.

Second, of the companies disclosing CSR spending in the prospectus, more money was spent in the years leading up to the IPO date, this further suggests that CSR spending is likely only used by companies to show regulators and potential investors about their participation in CSR but the amount spent may not be something that can be considered generous.

Third, only company size was found as a significant determinant of CSR spending in the sample companies. This is in line with prior studies suggesting that large companies have more resources to finance CSR activities. Large companies tend to have more public scrutiny; thus, CSR spending may build a stronger bond with stakeholders. Ogola and Dreer (2012) also support this, who argue that CSR spending is carried out to win the market competition.

Another factor that can also be noted is that company profits do not have a significant relationship with CSR Spending, and this shows that profit is not a driving force for CSR spending in our sample companies, this indicates that if they do not have a solid motivation to spend on CSR activities, they still won't do it regardless of the availability of money. However, the strategy taken by the company seems to be in line with the Resource Dependency Theory, where the company needs to develop certain strategies to increase its success (Adomako \& Nguyen, 2020; Frynas \& Yamahaki, 2016).

\section{CONCLUSION, LIMITATIONS, AND SUGGESTIONS}

\section{Conclusion}

The results show that the majority of our sample companies disclose some level of CSR items in their prospectus, but only a fraction of companies disclose the amount spent on their CSR activities. The companies disclosing CSR expenditures allocate more spending in the years leading up to the IPO date (y) than the prior years. So the spending on $y$ is relatively higher, compared to that of $y-1$. This pattern also continues to $y-2$ and $y-$ 3. We also find that CRS spending is significantly and positively associated with the company size. This finding is robust to alternative specifications.

We also find that firm age and auditor reputation have a negative and significant relationship with CSR expenditure, but this relationship does not persist in our three robustness tests. Other company attributes tested in this research model, namely profit, leverage, underwriter reputation, and the industry do not show any relationship with CSR expenditure. Overall, this study confirms the existing literature that CSR performance is for strategic and compliance purposes so that its performance.

This study makes important contributions to the existing CSR disclosure literature through the following channels. First, this study provides the first Indonesian empirical 
evidence on the disclosure of the CSR Spending in the IPO prospectuses. Second, in contrast to other CSR studies that primarily focus on company annual reports, this study extends the previous research by utilizing a new dataset from the prospectuses of IPO companies and examining the factors influencing the disclosure of voluntary CSR spending. Third, this study also provides future direction for the Indonesian academic community, regulators, professional bodies, and investors to emphasize further CSR reporting practice, particularly disclosure of CSR expenditures and research.

\section{Limitation and suggestions}

Our results are subject to the limitations listed below, along with suggestions for future research on how to overcome the issue. First, this study involves manual data collection; thus, this study is subject to human error and judgment. However, we have attempted to use several applicable methods to mitigate the potential bias to our results during the data mining and analysis. Furthermore, this limitation also applies to all other studies that have employed content analysis in data collection. Thus, we predict that this limitation does not significantly affect our results. For improved data accuracy, further research may utilize research data generated by computerized systems such as databases, e.g., Datastream, which we did not have access to.

Second, a number of prospectuses under consideration were issued way back in 2012. As we believe there have been some improvements in CSR disclosure due to government regulations or increased awareness of issuing companies about the benefits of CSR disclosure, our research findings may not be quite relevant to the current level of disclosure practice. While this limitation does not affect the results, it is pertinent to consider a limitation as it affects the interpretation of the results. Further studies could include an IPO prospectus published in 2020. Indonesia is starting to mandate sustainability in the capital market, so it will be interesting to see how prospective IPO companies will respond to the mandatory CSR requirements.

\section{Acknowledgment (if any)}

The completion of this paper would not have been possible without the hard work and commitment given by two alumni of the Syiah Kuala University International Accounting Program (USK - IAP), namely Putra Maswan and Ghalda Classica, in the data collection process. Therefore we would like to thank them for their contributions.

\section{REFERENCES}

Adomako, S., \& Nguyen, N. P. (2020). Interfirm collaboration and corporate social responsibility expenditure in turbulent environments: The moderating role of entrepreneurial orientation. Corporate Social Responsibility Environmental Management, 27(6), 2668-2678. https:// doi.org/10.1002/csr.1991

Albuquerque, R., Durnev, A., \& Koskinen, Y. (2013). Corporate social responsibility and firm risk: Theory and empirical evidence: Centre for Economic Policy Research.

Ali, S. M., \& Isa, M. A. (2018). Firms attributes and corporate social responsibility disclosure: A literature review. International Journal of Academic Research in Business and Social Sciences, 8(4), 312- 325. https://doi.10.6007/IJARBSS/v8i4/ 4016

Ali, W., Frynas, J. G., \& Mahmood, Z. (2017). Determinants of corporate social responsibility (CSR) disclosure in developed and developing countries: A 
literature review. Corporate Social Responsibility Environmental Management, 24(4), 273-294. https:/ / doi.org/10.1002/csr.1410

Andersen, M. L., Dejoy, J.S. (2011). Corporate social and financial performance: the role of size, industry, risk, rand and advertising expenses as control variables. . Business and Society Review, 116(2), 237-256. https://doi.org/10.1111/j.14678594.2011.00384.x

Arenas-Parra, M., \& Álvarez-Otero, S. (2020). CSR Disclosure: The IPO Case. Sustainability, 12(11), 4390.

Arora, A., \& Soni, T. K. (2017). Corporate social responsibility and firm characteristics: Evidence from BSE 500. International Journal of Information, Business Management Decision, 9(1), 119. https://10.24198/jaab.v3i1.26228

Baluja, G. (2017). CSR practices by banks: A comparative study. International Journal of Engineering Technology, Management Applied Sciences, 2349-4476.

Bhaduri, S. N., \& Selarka, E. (2016). Corporate Social Responsibility Around the WorldAn Overview of Theoretical Framework, and Evolution. In Corporate Governance and Corporate Social Responsibility of Indian Companies (pp. 11-32). Singapore: Springer Singapore. https://doi.org/10.1007/978-981-10-0925-9_2

Bhattacharyya, A., \& Rahman, M. L. (2019). Mandatory CSR expenditure and firm performance. Journal of Contemporary Accounting Economics 15(3), 100163. https://doi.org/10.1016/j.jcae.2019.100163

Bird, R., D. Hall, A., Momentè, F., \& Reggiani, F. (2007). What corporate social responsibility activities are valued by the market? Journal of Business Ethics, 76(2), 189-206. https:/ / doi.org/10.1007/s10551-006-9268-1

Darmawan, I., \& Setiono, J. (2020). Indonesia sustainability series: Obligation to submit sustainability report in 2021. https://globalcompliancenews.com/indonesiasustainability-series-obligation-to-submit-sustainability-report-in-2021-05102020/

Dawkins, C. E., \& Fraas, J. W. (2013). An exploratory analysis of corporate social responsibility and disclosure. Business Society, 52(2), 245-281. https://doi.org/10.1177/0007650308324047

Derwall, J. (2007). The economic virtues of SRI and CSR. (Doctoral), Erasmus University, Rotterdam. Retrieved from http://repub.eur.nl/res/pub/8986/ESP2007101F\%26A9058921328DERWALL.pdf

Desai, N., Viswanath, P., \& Tripathy, A. (2015). Is 2\% the solution? Experimental evidence on the new CSR rule in India. Economics at your fingertips, W.P. No. 2015-03-09

Engman, D., \& Hagström, L. (2017). Disclosure trends in CSR reporting. (Master), Jönköping International Business School, Jönköping.

Feng, Z.-Y., Chen, C. R., \& Tseng, Y.-J. (2018) Do capital market value Corporate Social Responsibility? Evidence from seasoned equity offerings," Journal of Banking and Finance, Elsevier, vol. 94(C), page 54-74. https://doi.org.10.1016/j.jbankfin.2018.06.015 
Frynas, J. G., \& Yamahaki, C. (2016). Corporate social responsibility: Review and roadmap of theoretical perspectives. Business Ethics: A European Review, 25(3), 258-285. https://doi.org/10.1111/beer.12115

Goss, A., \& Roberts, G. (2011). The impact of corporate social responsibility on the cost of bank loans. Journal of Banking \& Finance, 35(7), 1794-1810. https://doi.org/10.1016/j.jbankfin.2010.12.002

Hartomo, G. (2021). Ini Penjelasan BEI Terkait Pergantian Indeks JASICA ke IDX-IC. https://www.idxchannel.com/market-news/ini-penjelasan-bei-terkaitpergantian-indeks-jasica-ke-idx-ic

Huang, F., Xiang, L., Liu, R., Su, S., \& Qiu, H. (2019). The IPO corporate social responsibility information disclosure: Does the stock market care? Accounting Finance, 59, 2157-2198. https:/ / doi.org/10.1111/acfi.12534

Jain, N., \& Mishra, S. S. (2011). Firm characteristics and CSR rating: empirical evidence from India. Paper presented at the National Conference on Corporate Social Responsibility Issues and Challenges, Allied Publishers Pvt. Ltd.

KB Bukopin. (2019). Ernst \& Young sebut Indonesia peringkat 10 besar dunia untuk jumlah IPO 2018. https://emitennews.com/ernst-young-sebut-indonesiaperingkat-10-besar-dunia-untuk-jumlah-ipo-2018/

Li, W., \& Zhang, R. (2010). Corporate social responsibility, ownership structure, and political interference: Evidence from China. Journal of Business Ethics, 96(4), 631645 .

Malik, M., Al Mamun, M., \& Amin, A. (2019). Peer pressure, CSR spending, and longterm financial performance. Asia-Pacific Journal of Accounting Economics, 26(3), 241-260. https:/ / doi.org/10.1080/16081625.2018.1493933

McElhaney, K. (2009). A strategic approach to corporate social responsibility. Leader to Leader, 52(1), 30-36.

McWilliams, A., \& Siegel, D. (2000). Corporate social responsibility and financial performance: Correlation or misspecification? Strategic Management Journal, 21(5), 603-609.

Michelon, G., Pilonato, S., \& Ricceri, F. (2015). CSR reporting practices and the quality of disclosure: An empirical analysis. Critical Perspectives on Accounting, 33, 59-78. https://doi.org/10/1016/j.cpa.2014.10.003

Mohanty, J. (2014). Who decides on what to spend in CSR? Moving from compulsion to consensus. International Proceedings of Economics Development and Research, 79, 77. https:// doi.org/10.7763/IPEDR.2014.V79.14

Mukherjee, A., \& Bird, R. (2016). Analysis of mandatory CSR expenditure in India: A survey. International Journal of Corporate Governance, 7(1), 32-59. https:/ / doi.org/10.1504/IJCG.2016.077982

Mukherjee, A., \& Chaturvedi, R. (2013). From CSR to MCSR: The Journey Towards Mandatory Corporate Social Responsibility in India. 
Newsy Today. (2021). Officially, Starting Today, IDX Group Issuers in 12 Sectors. https://www.newsy-today.com/officially-starting-today-idx-group-issuers-in-12sectors/

Nollet, J., Filis, G., \& Mitrokostas, E. (2016). Corporate social responsibility and financial performance: A non-linear and disaggregated approach. Economic Modelling, 52, 400-407. https:/ / doi.org/10/1016/j.econmod.2016.09.019

Ogola, F. O., \& Dreer, T. (2012). Market share as an indicator for corporate social responsibility (CSR) spending: The study of Coca Colas market. African Journal of Business Management, 6(6), 2234-2247. https://doi.org/10.5987/ABJM11.2133

Oh, W. Y., Chang, Y. K., \& Martynov, A. (2011). The effect of ownership structure on corporate social responsibility: Empirical evidence from Korea. Journal of Business Ethics, 104(2), 283-297. https:/ / doi.org/10.1007/ s10551-011-0912-z

OJK. (2016). OJK: Syarat lengkap, proses IPO bisa 3 hari.

OJK. (2017). Peraturan Otoritas Jasa Keuangan: Tentang bentuk dan isi prospektus dan prospektus ringkas dalam rangka penawaran umum efek bersifat ekuitas). No. 8 /POJK.04/2017. https://gopublic.idx.co.id/2016/06/22/ peraturan-go-public/

Oke Finance. (2019). Indonesia masuk peringkat ke-10 pasar IPO global. https:// economy.okezone.com/read/2019/07/24/320/2082951/indonesiamasuk-peringkat-ke-10-pasar-ipo-global?page $=3$

Pérez-López, D., Moreno-Romero, A., \& Barkemeyer, R. (2015). Exploring the relationship between sustainability reporting and sustainability management practices. Business Strategy the Environment, 24(8), 720-734. https://doi.org/10.1002/bse.1841

Petrenko, O. V., Aime, F., Ridge, J., \& Hill, A. (2016). Corporate social responsibility or CEO narcissism? CSR motivations and organizational performance. Strategic Management Journal, 37(2), 262-279. https:/ / doi.org/10.1002/smj.2348

Piacentini, M., MacFadyen, L., \& Eadie, D. (2000). Corporate social responsibility in food retailing. International Journal of Retail Distribution Management. https://doi.org/10.1108/09590550010356822

Russo-Spena, T., Tregua, M., \& De Chiara, A. (2018). Trends and drivers in CSR disclosure: A focus on reporting practices in the automotive industry. Journal of Business Ethics, 151(2), 563-578. https://10.1007/s10551-016-3235-2

Russo, A., \& Perrini, F. (2010). Investigating stakeholder theory and social capital: CSR in large firms and SMEs. Journal of Business Ethics, 91(2), 207-221. https://doi.org/10.007/s10551-009-0079-z

Russo, M. V., \& Fouts, P. A. (1997). A resource-based perspective on corporate environmental performance and profitability. Academy of Management Journal, 40(3), 534-559. doi:10.5465/257052 https://doi.org/10.5465/257052

Sharma, C. S. K. (2013). A 360 degree analysis of Corporate Social Responsibility (CSR) mandate of the new Companies Act, 2013. Global Journal of Management and Business Studies, 3(7), 757-762. 
Singh, A., \& Verma, P. (2014). CSR@ 2\%: A new model of corporate social responsibility in India.

Smith, A. (2018). Fortune 500 companies spend more than $\$ 15 \mathrm{bn}$ on corporate responsibility. Retrieved from https://www.ft.com/content/95239a6e-4fe0-11e4a0a4-00144feab7de

Tendolkar, A. (2019). More companies spending on CSR but aren't being generous enough.

UCLA. (2021). Robust regression: Stata data analysis examples.

Varottil, U. (2018). Analysing the CSR spending requirements under Indian company law. In Globalisation of Corporate Social Responsibility and its Impact on Corporate Governance (pp. 231-253): Springer. https://doi.org/10.1007/978-3-319-691282_10

Verma, D., \& Jain, N. (2019). CSR stipulations of Companies Act, 2013 and actual CSR expenditure by top Indian companies prior to its implementation: A comparative study. Available at SSRN 3453686. https:/ / doi.org/10.2139/ssrn.3453686

Visser, W. (2012). Corporate sustainability \& responsibility: An introductory text on CSR theory \& practice-past, present \& future: BookBaby.

Zuraida, Z., \& Sugianto, S. (2019). An inherent ambiguity of CSR disclosure concept: Evidence from IPO prospectuses of indonesian listed companies. Paper presented at the 1st Aceh Global Conference (AGC 2018). https://doi.org/10.2991/agc18.2019 .66 